\title{
THE USE OF VIRTUAL MECHATRONICS IN TEACHING COURT DECISION ANNOTATION DURING THE COVID-19 PANDEMIC
}

\author{
USEP SAEPULLAH
}

Faculty of Sharia and Law, UIN Sunan Gunung Djati Bandung, Indonesia

\begin{abstract}
This research is motivated by the phenomena that the more widespread of the Corona Diseases Virus 2019 (Covid-19) pandemic has prompted the government and stakeholders to handle this case systematically and massively. Until now, many governments in various countries have taken repressive measures such as tight territory restrictions (lockdown), social restrictions (social distancing), and called on people to work from home, learn from home, and worship from home. This also occurs in the process of legal studies learning in universities, where the lecturers and students take policies and solutions by conducting online learning. The court decision analysis learning in law faculties is usually carried out in the classroom through face-to-face, presentations, discussions, and simulations, but after applying a large-scale social restriction policy due to Covid-19, they changes learning methods through various online-based applications, such as $E$ knows, Google Classroom, Zoom Meeting, Whatsapp, and so forth. In practice, they also use virtual mechatronics and annotation methods to improve the students understanding in the subject of court decisions analysis learning. The finding of this research indicates that the combination of the use of virtual mechatronics media is evidently increased the understanding and learning outcome of the students in the subject of court decision annotations.

KEYWORDS: Covid-19, Virtual Mechatronics, Teaching, Annotation, Court Decisions
\end{abstract}

Received: Apr 26, 2020; Accepted: May 17, 2020; Published: Jun 30, 2020; Paper Id.: IJMPERDJUN2020209

\section{INTRODUCTION}

The case of Corona Virus Disease (Covid-19) has not only been a pandemic disaster that has plagued various countries, but has also had widespread and massive influenced on various aspects of people's lives. Covid-19 was first discovered in Wuhan City, China at the end of December 2019 [1]. In a very short time, this deadly virus turned out has spread very quickly and widely to almost all countries in the world, including Indonesia [2]. Until now, at least 15 countries around the world have confirmed the existence of corona virus cases.Each countryhas confirmed the existence of Covid-19 cases, the number of death cases, and the recovery of patients varies. The most cases are recorded in the United States, which are more than 900,000 cases stated positive and more than 50,000 people stated death [3].

The government of Indonesia stated that until May 10, 2020, the accumulation of Covid-19 cases in Indonesia has reached 14,023 cases. The rapid tests using the Polymerase Chain Reaction (PCR) showed that 13,879 people are positive. Meanwhile, the Molecular Rapid Test (MRT) showed that 153 people are stated positive. Totally, 14,032 people were declared positive, and from this accumulation the number of patients dying continued to grow [4]. In the last 24 hours, there were 14 patients who died so that the accumulation became 973 peoples. Meanwhile, the number of patients who were declared cured also continued to grow. In the last 24 hours, there were 91 patients who tested negative for the corona virus through two tests, namely the Swab Test or 
Polymerase Chain Reaction (PCR). Thus, the accumulation of cured patients was 2,698 people [5].

The negative impact of Covid-19 has changed the whole structure of people's lives in various sectors, such as socially, educationally, and economically [6]. This condition has encouraged the lecturers at universities to map comprehensively about the right learning model and must be applied to the students. They have no other choice except learning innovation which they can still teach continuously and the students are also able to receive learning materials [7]. This choice is a logical consequence of the outbreak of the Covid-19 pandemic disaster which affected to the education system. To avoid the wider spread of Covid-19, the Indonesian government was forced to adopt a policy strictly for social restrictions in the form of staying at home, working from home, studying at home, and also worshiping at home [8].

The spread of the Covid-19 pandemic has also resulted many students have to carry out various learning activities at home, both online and offline [9]. However, not all students and lecturers have the ability to access online learning platforms optimally. In the midst of this unpredictable provision, there are not several encounter ways, including facilities, internet networks, mastery of information technology, availability of teaching materials, and so on. In addition, of course, these difficulties are also feeling saturations resulted among certain people today, like depression and stress due to the lack of social interaction and direct communication [10].

One of the interesting phenomena carried out comprehensively in this paper is not to explore the problem or medical impact of the spread of Covid-19, but the problems and impact of the Covid-19 disaster on teaching the court decision annotation at Faculty of Sharia and Law. In some cases, the lecturers and students still find difficulties in choosing the right learning method and the effective learning media during the periods of social quarantine or social restrictions. In addition, a number of lecturers at Faculty of Sharia and Law, UIN Sunan Gunung Djati Bandung today still find a number of the difficulties about how to deliver the teaching materials of court decision annotation to law students during the Covid-19 pandemic, both luring and daring, and especially in line of using virtual mechatronics approach.

Virtual mechatronics can be defined as the perfect tool to step into the world of industrial automation. The students acquire basic theoretical knowledge for every single technology prior to the hands-on and skill-based training, which is performed on real equipment. The genealogy of virtual mechatronics is derived from the term of "mechatronics" in English, and "mechatronik" in Germany. The word is very popular studied in mechanical science, electronics, computer, and informatics engineering [11].

The word mechatronics originated in Japanese-English and was created by Tetsuro Mori, an engineer of Yaskawa Electric Corporation. It was also registered as trademark by the company in Japan with the registration number of "46$32714 "$ in 1971. However, afterward the company released the right of using the word to public, the word begun being used across the world. The word is translated into many languages and the word is considered as an essential term for modern industry [12]. According to Mechanical and Mechatronics Engineering Department, French standard NF E 01-010 gives the following definition: "approach aiming at the synergistic integration of mechanics, electronics, control theory, and computer science within product design and manufacturing, in order to improve and/or optimize its functionality" [13].

In some specific literatures, virtual mechatronics is also inherent with the term of mechatronic engineering, which is a multidisciplinary branch of engineering that focuses on the engineering of both electrical and mechanical system, and also includes a combination of robotics, electronics, computer, telecommunication, system control, and product 
engineering [14]. In simply, virtual mechatronics is atechnology advances over time, used to various subfields of engineering, and have succeeded in both adapting and multiplying [15].

Based on the description above, this paper will be focused on the expertise of a small number of the lecturers at Department of Islamic Court, Faculty of Sharia and Law, UIN Sunan Gunung Djati Bandung, West Java, Indonesia who have succeeded in carrying out several innovations in the learning process. Some of them also have used a virtual mechatronics approach in the court decisions annotation learning process. Even though they still find various difficulties caused by the limitations in knowledge, understanding, and skills, but they have used internet network facilities through the use of virtual mechatronics quite effectively to improve the student ability to master in the subject of court decision annotation learning process.

\section{RESEARCH METHOD}

This research uses the combination between bibliographical and empirical method. This method is used to describe the influence of the use of virtual mechatronics and court decision annotation methods to improve the students understanding in the subject of court decisions analysis learning during the Covid-19 pandemic social restriction period at Department of Islamic Court, Faculty of Sharia and Law, UIN Sunan Gunung Djati Bandung, West Java, Indonesia. Primary, secondary, and tertiary data sources are derived from the number of literatures and interview results that are closely related to the research objective. While the data collection techniques obtained from book review, documentation, in-depth interview to the lecturers and students, and the other sources that relevant with the main topic of the research in line of the influence of the use of virtual mechatronics and court decision annotation methods to improve the students understanding in the subject of court decisions analysis learning during the Covid-19 pandemic social restriction period.In the last step, analysis of the data consists of the steps of compilation, classification, and analysis of the data which are done deductively and inductively until the formulation of conclusion.

\section{RESULT AND DISCUSSION}

Observing the situation developed during the emergency Pandemic Covid-19 disaster lately, the entire academic community of universities in Indonesia, including at UIN SunanGunungDjati Bandung, has forcedto implement academic and non-academic policies in online way. This situation did not dampen the enthusiasm and steps of the entire academic at Faculty of Sharia and Law and Law, UIN SunanGunungDjati Bandung to be able to continue to carry out academic and non-academic services to the law students in the form of learning, guidance, consultation, and examinations/evaluations through various online ways and using various virtual media with a principle of optimizing the facilities, energy, time, effectiveness, and flexibility of possessed with the aim not to further complicate and aggravate the current conditions [16].

Based on the reason, the academic decision makers view that they have evaluated and compiled a learning program report as a consideration for all parties to formulate policies and implement further steps in providing academic and non-academic services to the students at the Faculty of Sharia and Law, UIN Sunan Gunung Djati Bandung. From the enactment of the emergency period and prevention of the spread of Pandemic Covid-19 through the Chancellor Circular Letter Number: 384/Un.05/II.4/HM.01/03/2020 dated March 30, 2020 on the Amendment to the Chancellor Circular Letter Number: 353/Un.05/II.4/HM.01/03/2020 on the Follow-Up Prevention of Corona-19 Virus Spread at UIN Sunan Gunung Djati Bandung, allow them to review a number of points related to the policy implementation of academic and nonacademic activities at Faculty of Sharia and Law, UIN Sunan Gunung Djati Bandung [17]: 
- Academic and non-academic policies at Faculty of Sharia and Law, UIN SunanGunungDjati Bandung in principle continue to coordinate, synergize, and strengthen the academic and non-academic with university policies;

- Faculty of Sharia and Law, UIN SunanGunungDjati Bandung gives full freedom to the lecturers to provide academic services to the law students in the form of learning, guidance, consultation, and examinations/evaluations proportionately and rationally without ignoring academic and scientific norms and norms, by utilizing all types of online-based virtual media applications, both in the form of E-Learning service facilities provided by Center for Information Technology and Data Base (PTIPD) through various online applications, both are https://sapa.uinsgd.ac.id and other virtual media such as Zoom Meeting, Google Classroom, Cisco WebEx, Skype, etc., or through social media such as Email, Whatsapp, Instagram, Telegram, YouTube, etc;

- All Administration Staff and Education Personnel continue to provide academic administrative services to the Law students in online services through Electronic Documents (Certificates, Approval Signatures, and so forth in the form of MS Word convert to PDF) on standard templates that have been available and prepared by the Department/Study Program in advance previously coordinated with the Lecturer, Chair/Secretary of the Department and the Dean/Deputy Dean;

- Other matters in the form of taking academic documents directly (face to face) such as Certificate Diplomas, Value Transcripts, Copies of Accreditation, and Legalization of Certificate Diplomas are temporarily still avoided, except for very emergency reasons and urgently will be allowed by first getting approval from the Faculty Leaders (Dean/Vice Dean) and get permission or access to the campus area from the related party (Police or Security).

The implication of the implementation of the policy shows that the lecture process is still going on well by the lecturers and students online. One interesting phenomena can be seen in the use of virtual technology and court decision annotation methods to improve the students understanding in the subject of court decision analysis learning during the Covid-19 pandemic social restriction period at Department of Islamic Court, Faculty of Sharia and Law, UIN Sunan Gunung Djati Bandung, West Java, Indonesia. This table explains the influence of the use of virtual mechatronics approach to the student learning outcomes in understanding of court decision annotation method [18].

Table 1: Virtual Mechatronics, Court Decision Annotation, and Learning Outcomes

\begin{tabular}{|l|l|l|}
\hline $\begin{array}{c}\text { Virtual } \begin{array}{c}\text { Mechatronics \& } \\
\text { Court Decision } \\
\text { Annotation }\end{array} \\
\text { The use of virtual } \\
\text { mechatronics and the } \\
\text { subject court decision } \\
\text { annotation }\end{array}$ & $\begin{array}{l}|c| \\
\text { Most lecturers have ability, knowledge, } \\
\text { and skills to use virtual mechatronics as an } \\
\text { effective media for online learning during } \\
\text { the Covid-19 pandemic }\end{array}$ & $\begin{array}{l}\text { Most students have ability to know and } \\
\text { understand to use virtual mechatronics as an } \\
\text { effective media for online learning during the } \\
\text { Covid-19 pandemic }\end{array}$ \\
\cline { 2 - 3 } & $\begin{array}{l}\text { A small number of lecturers have ability to } \\
\text { teach the subject court decision } \\
\text { annotations through online way during the } \\
\text { Covid-19 pandemic }\end{array}$ & $\begin{array}{l}\text { A small number of students have ability to } \\
\text { know and understand the subject of court } \\
\text { decision annotations through online way } \\
\text { during the Covid-19 pandemic }\end{array}$ \\
\hline \multirow{2}{*}{$\begin{array}{l}\text { Arranging Learning } \\
\text { Plans }\end{array}$} & $\begin{array}{l}\text { Most lecturers have ability in arranging } \\
\text { learning plan through the use of virtual } \\
\text { mechatronics in online learning on } \\
\text { thesubject of court decision annotations } \\
\text { during the Covid-19 pandemic }\end{array}$ & $\begin{array}{l}\text { Most students have ability in understanding } \\
\text { online learning plan through the use of virtual } \\
\text { mechatronics in the subject court decision } \\
\text { annotations during the Covid-19 pandemic }\end{array}$ \\
\hline
\end{tabular}


Table 1: Contd.,

\begin{tabular}{|l|l|l|}
\hline $\begin{array}{l}\text { Learning process } \\
\text { constraints }\end{array}$ & $\begin{array}{l}\text { Most lecturers have ability to use virtual } \\
\text { mechatronics to solve the constraints of } \\
\text { online learning process on the subject of } \\
\text { court decision annotations during the } \\
\text { Covid-19 pandemic }\end{array}$ & $\begin{array}{l}\text { Most students have ability to use virtual } \\
\text { mechatronics to solve the constraints of online } \\
\text { learning process on the subject of court } \\
\text { decision annotations during the Covid-19 } \\
\text { pandemic }\end{array}$ \\
\hline $\begin{array}{l}\text { Learning strategies } \\
\text { and outcomes }\end{array}$ & $\begin{array}{l}\text { Most lecturers have various learning } \\
\text { strategies in online learning process on the } \\
\text { subject court decision annotations through } \\
\text { the use of virtual mechatronics during the } \\
\text { Covid-19 pandemic }\end{array}$ & $\begin{array}{l}\text { Students learning outcomes are very good in } \\
\text { knowledge, understanding, and skills aspects } \\
\text { through the use of virtual mechatronics in } \\
\text { online learning on the subject court decision } \\
\text { annotations during the Covid-19 pandemic }\end{array}$ \\
\hline
\end{tabular}

\section{Virtual Mechatronics and Court Decision Annotation}

In general, the intention of mechatronics is basically to produce a design solution that unifies each of these various subfields. Originally, the field of mechatronics was intended to be nothing more than a combination of mechanics and electronics, hence the name being a portmanteau of mechanics and electronics; however, as the complexity of technical systems continued to be evolved, the definition had been broadened to include more technical areas [19]. Until now, virtual mechatronics approach is not only used by the lectures at Faculty ofScience and Technology, but also very familiar with other lectures who teach the subject of court decision annotation at Faculty of Sharia and Law, UIN SunanGunungDjati Bandung, Indonesia.

They practiced of virtual mechatronics through various methods and approaches with these highlights: first, webbased training packages (WBTs) combined and managed via Classroom Manager; second, programming and simulation software to develop programming skills in different technologies; third, classroom manager as the quick and easy way to create, manage and supervise training sessions and courses; fourth, Excellent didactic and multimedia course topics; learning scenarios can be individually customized; and fifth, connected learning with Tec2Screen as an innovative learning methodology that makes complex technologies easy to understand [20].

Based on the in-depth interview with the number of lecturers and students at Department of Islamic Court, Faculty of Sharia and Law, UIN Sunan Gunung Djati Bandung, this short empirical research showed that they have various abilities regarding on their understanding, knowledge, and skills on the use of virtual mechatronics as an effective media for online learning during the Covid-19 pandemic [21]. Most of them have ability, knowledge, and skills to use virtual mechatronics but a small number of lecturers have ability to teach the subject court decision annotations through online way during the Covid-19 pandemic.

Table 2: The Ability of Lecturers and Students in the Use of Virtual Mechatronics and the Subject of Court Decision Annotations

\begin{tabular}{|l|l|l|l|}
\hline \multicolumn{1}{|c|}{ Lecturers \& Students } & \multicolumn{1}{c|}{ Knowledge Ability } & \multicolumn{1}{c|}{ Understanding Ability } & Skills Ability \\
\hline RWS (L) & Excellent & Excellent & Excellent \\
\hline BH (L) & Excellent & Excellent & Excellent \\
\hline DKY (L) & Excellent & Excellent & Excellent \\
\hline MSK (L) & Excellent & Very Good & Very Good \\
\hline MSNF (L) & Excellent & Very Good & Very Good \\
\hline NA (S) & Excellent & Excellent & Excellent \\
\hline NTAH (S) & Excellent & Excellent & Excellent \\
\hline MN (S) & Excellent & Very Good & Very Good \\
\hline AW (S) & Excellent & Very Good & Very Good \\
\hline LA (S) & Excellent & Very Good & Very Good \\
\hline
\end{tabular}


The table 2 shows five lecturers at Faculty of Sharia and Law, UIN Sunan Gunung Djati Bandung have an excellent knowledge, understanding, and skills in the use of virtual mechatronics and the learning subject of court decision annotations. In contrast, there show that three lecturers, initially RWS, BH, and DKY, who are in charge of court decisions annotations have an excellent knowledge, understanding, and skills in the use of virtual mechatronics and the learning subject of court decision annotations compared to other lecturers at Faculty of Sharia and Law, UIN Sunan Gunung Djati Bandung, initially MSK and MSNF, who are very good in understanding and skills ability in the use of virtual mechatronics and the learning subject of court decision annotations. This is based on three aspects: first, they are indeed experts in this field; second, they have quite very long experience in this field; and third, they are also members of the court decision research team at Australia-Indonesia Partnership for Justice (AIPJ) and the Indonesian Supreme Court in collaboration with other researchers from MaPPI, PSHTN, LeIP, ICJR, and others.

The condition looks different from the student perspectives in the table above, which all of them, initially NA, NTAH, MN, AW, and LA, have very good knowledge in the use of virtual mechatronics in learning subjects of court decisions annotation at Department of Islamic Court, Faculty of Sharia and Law of UIN Sunan Gunung Djati Bandung. In the aspect of understanding and skills, there are differences, where NA and NTAH are excellent, while MN, AW, and LA are in very good category. This is based on three aspects: first, NA and NTAH often consult directly with expert lecturers, while $\mathrm{MN}$, AW, and LA are very rare; and secondly, NA and NTAH had experience in participating in information computer technology (ICT) training, whereas MN, AW, and LA had never been at all; and third, NA and NTAH had experience in participating in court decisions annotation research team with the lecturers, whereas MN, AW, and LA had also never been at all.

\section{The Lectures and Students Ability in Arranging Learning Plan}

In general, the following table shows that most lecturers have ability in arranging learning plan through the use of virtual mechatronics in online learning on the subject of court decision annotations during the Covid-19 pandemic. It is also followed by most students have also ability in understanding online learning plan arranged by the lecturers during the Covid-19 pandemic.

Table 3: The Ability of Lecturers and Students in Arranging Learning Plan through the Use of Virtual Mechatronics in the Learning Subject of Court Decision Annotations

\begin{tabular}{|l|l|l|l|}
\hline \multicolumn{1}{|c|}{ Lecturers \& Students } & \multicolumn{1}{c|}{ Knowledge Ability } & \multicolumn{1}{c|}{ Understanding Ability } & \multicolumn{1}{c|}{ Skills Ability } \\
\hline RWS (L) & Excellent & Excellent & Excellent \\
\hline BH (L) & Excellent & Excellent & Excellent \\
\hline DKY (L) & Excellent & Excellent & Excellent \\
\hline MSK (L) & Excellent & Very Good & Very Good \\
\hline MSNF (L) & Excellent & Very Good & Very Good \\
\hline NA (S) & Very Good & Very Good & Very Good \\
\hline NTAH (S) & Very Good & Very Good & Very Good \\
\hline MN (S) & Very Good & Very Good & Very Good \\
\hline AW (S) & Very Good & Very Good & Very Good \\
\hline LA (S) & Very Good & Very Good \\
\hline
\end{tabular}

The table 3 shows five lecturers at Faculty of Sharia and Law, UIN Sunan Gunung Djati Bandung have an excellent ability in arranging online learning plan through the use of virtual mechatronics on the subject of court decision annotations during the Covid-19 pandemic. There are three lecturers, who are initially RWS, BH, and DKY have an excellent knowledge, understanding, and skills in arranging online learning plan through the use of virtual mechatronics on 
the subject of court decision annotations during the Covid-19 pandemic, and two lecturers, who are initially MSK and MSNF very good. The table 3 shows that all students, who are initially NA, NTAH, MN, AW, and LA, have very good ability in knowledge, understanding, and skills about online learning plan through the use of virtual mechatronics on the subject of court decision annotations during the Covid-19 pandemic arranged by the lecturers.

It is make sense that in general, virtual mechatronics approach is commonly used in the learning of applied science such as mathematics, biology, physics, chemistry, electrical engineering, informatics engineering, civil engineering, agricultural technology, robotics, etc. [22]. However, virtual mechatronics approach also seems to be used in the subject of legal studies in certain study programs that require teaching tools, such as conducted by the lecturers at Department of Islamic Court, Faculty of Sharia and Law, UIN Sunan Gunung Djati Bandung, West Java, Indonesia.

The learning plan is prepared in one semester which includes 16 meetings that formulate a theoretical and practical approaches with an average credit weight of 3 credits per course, 24 credits per semester, a minimum total of 144 credits and a maximum of 160 credits during the study period, including the examination of undergraduate research thesis qualifications and presentations. Learning materials and sub-materials are arranged systematically based on the consideration of time, the availability of teaching materials, the completeness of learning facilities and infrastructures, and the number of students, especially methods, approaches, strategies, techniques, and evaluation of learning process [23].The result of empirical research shows that the lecturers teach the subject court decision annotation to students with a various approaches, one of which is using a virtual mechatronics approach. This approach is applied simply in learning process [24].

\section{The Lectures and Students Ability to Solve the Learning Process Constraints}

In the following table shows that most lecturers and students at Department of Islamic Court, Faculty of Sharia and Law, UIN Sunan Gunung Djati Bandung have similar ability to use virtual mechatronics to solve the constraints of online learning process on the subject of court decision annotations during the Covid-19 pandemic within the average very good.

Table 4: The Ability of Lecturers and Students in Solving the Learning Process Constraints on the Subject of Court Decision Annotations through the Use of Virtual Mechatronics

\begin{tabular}{|l|l|l|l|}
\hline \multicolumn{1}{|c|}{ Lecturers \& Students } & \multicolumn{1}{c|}{ Knowledge Ability } & \multicolumn{1}{c|}{ Understanding Ability } & Skills Ability \\
\hline RWS (L) & Very Good & Very Good & Very Good \\
\hline BH (L) & Very Good & Very Good & Very Good \\
\hline DKY (L) & Very Good & Very Good & Very Good \\
\hline MSK (L) & Very Good & Very Good & Very Good \\
\hline MSNF (L) & Very Good & Very Good & Very Good \\
\hline NA (S) & Very Good & Very Good & Very Good \\
\hline NTAH (S) & Very Good & Very Good & Very Good \\
\hline MN (S) & Very Good & Very Good & Very Good \\
\hline AW (S) & Very Good & Very Good & Very Good \\
\hline LA (S) & Very Good & Very Good & Very Good \\
\hline
\end{tabular}

It is very interesting to be criticized and analyzed why they have similarly very good ability in the constraints of online learning process through the use of virtual mechatronics on the subject of court decision annotations during the Covid-19 pandemic. Even though all lecturers at Faculty of Sharia and Law, UIN Sunan Gunung Djati Bandung have similar ability in knowledge, understanding, and skills about the use of virtual mechatronics and the learning subject of court decision annotations, in fact they have different ability in practicing them to solve the constraints of the learning process which are similarly categorized in very good ability. These may be influenced by the differences of knowledge, 
understanding, skills, and experiences, especially several factors related with the learning process such as managing a time, place, class mastery, material object, the use of instructional media, learning strategies, learning communications, guidance and counseling, etc. Consequently, these are also implicated to the student ability which they will be in similar category in very good.

Practically, it can be conducted in several steps. In the beginning stages of learning process, the students are usually given a theoretical description of certain subject matter, for example the lecturer explains the conceptual framework of the change of liquid gas to freeze caused by climate change. Furthermore, the students are given an independent task to compile an essay about the review of lecture material that has been delivered by the lecturer [25]

In the second stage, the lecturer presented with power point shows about some concrete examples of the change of liquefied gas to freeze through various teaching aids, such as showing films, videos, photos, and simulations with various physical teaching tools. At this stage, the lecturer also divides students into several small groups and gives them group assignments to conduct mini-research on various objects in physics. For example, they are researching court decisions from directory that can be used as learning sources. The results of the field research are then compiled into a mini research report and presented in class by each group [26].

In the third stage, the lecturer provides a final evaluation and assessment, where the assessment is not only related to the ability of the students to know, understand, and simulate learning outcomes with a virtual mechatronics approach, but also to what extent they choose research objectives that understand about type of case, position case, legal considerations, and type of decision. In some cases, a number of students have no difficulties in doing it like its learning activities because they have already had the basic abilities of court decision annotations before. In fact, some of them found the difficulties in learning process because they do not have the basic skills and also less skilled in using teaching tools.

\section{The Lectures and Students Ability in Choosing Learning Strategies and Its Impact to the Student Learning Outcomes}

Practically, virtual mechatronics can beusedtosolve the learning process constraints on the subject of court decision annotations through the use of virtual mecha9tronicsduring the Covid-19 pandemic.Dick \& Carey [27] explained that learning strategies are the chosen ways to convey subject matter in a particular learning environment, including the nature, scope, and sequence of activities that can provide learning experiences to the students. They argue that learning strategies are not only limited to the procedure of activities, but also include learning materials or packages. The learning strategy consists of all components of the subject matter and procedures that will be used to help students achieve certain learning goals.

Gerlach \& Ely [28] explain that learning strategy can be interpreted as a pattern of learning activities that are selected and used by the teacher contextually, to be in accordance with the characteristics of the students, school conditions, the surrounding environment, and the specific learning objectives formulated. They also emphasize that there needs to be a link between learning strategies and learning objectives, in order to obtain effective and efficient of learning activities. In this regard, Newman, Logan, \& Makmun[29] explained that learning strategies is divided into two approaches: first, student-oriented or student-centered learning approaches; and second, learning-oriented or studentcentered approaches teacher (teacher centered approach). 
In the following table, most lecturers have ability in choosing various learning strategies to teach the students learning outcome through the use of virtual mechatronics in online way on the subject of court decision annotations during the Covid-19 pandemic.

Table 5: The Ability of Lecturers in Choosing Learning Strategies and Its Impact to the Students Learning Outcome through the Use of Virtual Mechatronics in the Learning Subject of Court Decision Annotations

\begin{tabular}{|l|l|l|l|}
\hline \multicolumn{1}{|c|}{ Lecturers \& Students } & \multicolumn{1}{|c|}{ Knowledge Ability } & \multicolumn{1}{c|}{ Understanding Ability } & \multicolumn{1}{c|}{ Skills Ability } \\
\hline RWS (L) & Excellent & Excellent & Excellent \\
\hline BH (L) & Excellent & Excellent & Excellent \\
\hline DKY (L) & Excellent & Excellent & Excellent \\
\hline MSK (L) & Excellent & Excellent & Very Good \\
\hline MSNF (L) & Excellent & Excellent & Very Good \\
\hline NA (S) & Excellent & Excellent & Excellent \\
\hline NTAH (S) & Excellent & Very Good & Excellent \\
\hline MN (S) & Excellent & Very Good & Very Good \\
\hline AW (S) & Excellent & Very Good & Very Good \\
\hline LA (S) & Excellent & Very Good \\
\hline
\end{tabular}

The table 5 almost the same with the result inthe table 1 and table 4 which the lecturers indicate in the excellent ability average in choosing various learning strategies to teach the students on the subject of court decision annotations through the use of virtual mechatronics in online way during the Covid-19 pandemic. It is inherent with the result test of the student ability in very good average that indicates $72 \%$ of 160 active students at Department of Islamic Court, Faculty of Sharia and Law, UIN Sunan Gunung Djati Bandung succeeded in exceeding the minimum learning outcomes criteria, i.e. they have passed with an average cumulative achievement 3.35 of 4.00 in the subject matter.

Finally, I can say that the virtual mechatronics cannot only be usedin learning process on the subject of decision annotation, but also can be used to other subjects. The important thing here, this can be seen as an alternative method to improve the students skills in the subject of court decisions annotation learning. The findings of this research indicate that the combination of the use of virtual mechatronics media and annotation methods is evidently increased the student learning outcomes in the subject of court decision annotations. Shortly, I can emphasize here that the use of virtual mechatronics is very effective and recommended to be used in online way during the Covid-19 pandemic, like evidently showed by the experience of learning process on the subject of court decision annotations at Department of Islamic Court, Faculty of Sharia and Law, UIN Sunan Gunung Djati Bandung, Indonesia.

\section{CONCLUSIONS}

Virtual mechatronics is very familiar in the world of industrial automation. It is basically a technological advances over time, used to various subfields of engineering, and have succeeded in adapting and multiplying the subject matter to produce a design solution that unifies each of various fields through the combination of mechanics and electronics. Nowadays, many governments in various countries have taken a strictly policies to encounter the Covid-19 pandemic through the tight territory restrictions or lockdown, social restrictions or social distancing, and called on people to work from home, learn from home, and worship from home. Consequently, it has also influenced to the lecturers at university to change the learning strategies from luring to daring, which they have used virtual mechatronics as an alternative approach in online learning process on the subjects of court decision annotation during the Covid-19 pandemic, like practiced at Department of Islamic Court, Faculty of Sharia and Law, UIN Sunan Gunun Djati Bandung, Indonesia. The result of the research indicates that the lecturers have very good ability in knowledge, understanding, and skills in the use of virtual 
mechatronics in learning process on the subject court decision annotation. It is impacted increase the student ability and learning outcomes that indicates $72 \%$ of 160 active students in very good average.

\section{REFERENCES}

1. Yunus. N. R.\&Rezki. A., (2020). "Kebijakan Pemberlakuan Lockdown sebagai Antisipasi Penyebaran Corona Virus Covid19", Salam: Jurnal Sosialdan Budaya Syar-i, 7(3).

2. Nabila. M. (2020), "Hadapi Covid-19: Strategi Pemasaran Pengembang Harus Beradaptasi"Availabe: https://ekonomi.bisnis.com/read/20200416/47/1228015/ hadapi-covid-19-strategi-pemasaran-pengembang-harusberadaptasi,retrieved onMay7, 2020.

3. Halim. D., (2020), “Update 10 Mei: Tambah 387, Kasus Covid-19 Jadi 14.023”, Available: https://nasional.kompas.com/read/2020/05/10/15451431/update-10-mei-tambah-387-kasus-covid-19-jadi-14023,retrieved on May 7, 2020.

4. Mukaromah. V. F. \&Ratiani, V.R. (2020). "Selain Vietnam, Ini Daftar 35 Negara dengan 0 Kematian Karena Covid-19", Available: https://www.kompas.com/tren/read/2020/ 04/25/204300865/selain-vietnam-ini-daftar-35-negara-dengan-0kematian-karena-covid-19, retrieved on May 7, 2020

5. Yuliana, (2020), "Corona Virus Diseases (Covid-19): Sebuah Tinjauan Literature", Welness and Healthy Magazines, 2(1), 187-192.

6. Ramadhan.Bagus, (2020). "Perubahan Perilaku Belanja Konsumen Indonesia Saat Covid-19", Available: https://teknoia.com/perilaku-konsumen-indonesia-saat-covid-19-ee51b041464e, retrieved on May 7, 2020.

7. Yusup, D. K., Badriyah, M., Suyandi, D., \&Asih, V. S. (2020).Pengaruhbencana Covid-19, pembatasansosial, dansistempemasaran online terhadapperubahanperilakukonsumendalammembeliproduk retail.http://digilib.uinsgd. ac. id, $1(1), 1-10$.

8. Pratama.E.,\&Rahayu. E., (2020), “Ekonomi Nasional Mulai Meradang Karena Covid 19”, Available: http://jurnalintelijen.net/2020/03/28/ekonomi-nasional-mulai-meradang-karena-covid-19/, retrieved on May 7, 2020.

9. Editor. (2039). "Analisis Pengaruh Covid-19 di Indonesia", https://covid19.go.id/retrieved on May 7, 2020.

10. Sccphd. (2020). "Information about Social Distancing", Available: https://www.cidrap. umn.edu/sites/default/files/public/php/185/185_factsheet_social_distancing.pdf retrieved on May 7, 2020.

11. Vesto, (2019), An Overview Learning through Virtual Mechatronics Approach in: https://www.festo-didactic.com/inten/highlights/turnkey-education-solutions/ overview-learning-environments/virtualmechatronics/?fbid=aW50LmVuLjU1Ny4xNy4xMC43NTI5LjQzNjM, retrieved on May 7, 2020.

12. Nutaro. James J., (2019). Building Software for Simulation: Theory and Algorithms, with Applicationsin C++.Wiley.Available: http://wikipedia.com/virtual/mechatronics, retrieved on May 7, 2020.

13. Mechanical and Mechatronics Engineering (MMED). (2011)."What is Mechatronics Engineering?", in Prospective Student Information, France, University of Waterloo, retrieved on May 7, 2020.

14. Bradley. David Allan, Loader. A.J., Burd. N.C. \& Dawson.David, (1993).Mechatronics, Electronics in Products and Processes, London, Chapman and Hall Verlag, 213-215.

15. Karnopp. Dean C., Margolis. Donald L.,\& Rosenberg. Ronald C., (2006). System Dynamics: Modeling and Simulation of Mechatronic Systems, $4^{\text {th }}$ Edition, Wiley, 193-195. 
16. The Chancellor Circular Letter Number: 353/Un.05/II.4/HM.01/03/2020 on the Prevention of Corona-19 Virus Spread at UIN Sunan Gunung Djati Bandung.

17. The Chancellor Circular Letter Number: 384/Un.05/II.4/HM.01/03/2020 on the Follow-Up Prevention of Corona-19 Virus Spread at UIN Sunan Gunung Djati Bandung.

18. Saepullah.U., (2020).The Use of Virtual Technology and Court Decision Annotation Methods in Court Decision Analysis Learning during the Covid-19 Pandemic Social Restriction Period at Department of Islamic Court, Faculty of Sharia and Law, UIN Sunan Gunung Djati Bandung. Short Empirical Research from February to April 2020.

19. Cetinkunt.Sabri,(2007).Mechatronics,New York, John Wiley \& Sons Inc.,245-249.

20. Priatna, T. (2019). The Impact of the Integration of Islamic Learning and Science through Virtual Mechatronics Approach to Student Learning Outcomes at UIN Sunan Gunung Djati Bandung, West Java, Indonesia. International journal of environmental and science education, 14(1), 481-482.

21. Saepullah.U., (2020). In-depth Interview Reports, Bandung, April 20-28, 2020.

22. De Silva. Clarence W., (2005).Mechatronics: An Integrated Approach, Research Report published in CRC Press, New York, $13-15$.

23. Onwubolu. Godfrey C., (2005). Mechatronics: Principles and Application, Amsterdam, Butterworth-Heinemann, 122-126.

24. J. Allan, \&K. Clarke, (2007). Nurturing Supportive Learning Environments in Higher Education Through the Teaching of Study Skills: To Embed or Not to Embed?, International Journal of Teaching and Learning in Higher Education, Vol. 19, No. 1, 64-76.

25. Rankers, Adrian M. (1997), Machine Dynamics in Mechatronics System,Enschede, University of Twente, 28-35.

26. Suhendi. H.Y.,Mulhayatillah. D., Anjani. R., Ramdani. M.A.,\& Ardiansyah. R., (2018), A Virtual Laboratory of Heat Transfer Concept in Microscopic Form, Proceding $3^{\text {rd }}$ Annual Applied Sciences and Engineering Conference (AASEC), Bandung, IOP Publishing, 1-6.

27. Dick. Walter, Carey. Lou,\& Carey. James O.., (2004).The Systematic Design of Instruction, New York, Harper Collion Publishers, 189-190.

28. Gerlach, V. S. \& Ely, D.P. (1980).Teaching and Media: A Systematic Approach, Prentice Hall, New Jersey, 1-3.

29. Newman, Logan, \& Makmun.Abin Syamsuddin.(2003), Psikologi Pendidikan., Bandung, Remaja Rosda Karya, 17-19.

30. Riad, Alaa M., Farahat F. Farahat, and Mahmoud A. Zaher. "Results of Zplag in Arabic E-Learning." International Journal of Computer Science and Engineering (IJCSE) 3.3 (2014):101-108

31. Ghorbani, Maryam., Fateme Noori Sarukolaee, and Madh. Dast-Mard. "The use of participatory learning method in training higher levels of learning in e-learning system." IMPACT: International Journal of Research in Humanities, Arts and Literature (IMPACT: IJRHAL) 2.7 (2014): 1-8.

32. Salim, Sherbin. "Exploring the Possibility of E-Learning in Teaching and Learning English as a Foreign Language in Government Higher Secondary Schools in Kerala." International Journal of Educational Science and Research (IJESR) 8.6 (2018):65-72

33. Hazari, Nida Fatima, and V. Vijaya Lakshmi. "Impact of E-Learning Education Intervention on Nutrition and Ealth Practices of Rural Women, its Correlation and Prediction with Socio Economic and Demographic Variables." International Journal of Educational Science and Research (IJESR) 7.5 (2017):109-116 
34. George, Aspridis., et al. "Assessment of e-Learning Methods in Public Administration. The Case of the Greek National School of Public Administration and Local Government." International Journal of Human Resource Management and Research (IJHRMR) 3.5 (2013): 19-36. 